\title{
THE FACTORS IN THE DEHYDRATION FOLLOWING PYLORIC OBSTRUCTION
}

\author{
By JAMES L. GAMBLE AND S. GRAHAM ROSS ${ }^{1}$ \\ (From the Department of Pediatrics, The Johns Hopkins Medical School)
}

(Received for publication, December 19, 1924)

\section{INTRODUCTION}

The data presented in this paper were obtained from several dogs following experimental obstruction of the pylorus. The experiments were undertaken with the purpose of learning the chief factors in the causation of the rapid dehydration which follows pyloric obstruction and of explaining the prevention or repair of this change which is obtained by introducing sodium chloride and water into the body.

In undertaking to investigate the cause of a reduction of the volume of body water it should at once be admitted that we have as yet only a fragmentary knowledge of the many parts of the regulatory mechanism which under usual circumstances accomplishes the remarkable adjustment of maintaining, in several elastic compartments, a closely stationary total volume of water. Certain gross data are, however, at hand which fairly satisfactorily serve the purposes of this study. It has been shown that in the presence of considerable reductions of the volume of body water the total concentration of dissolved electrolytes tends to remain stationary $(1,2)$. It is therefore probably permissible to postulate a close dependence of the volume of body water on the total quantity of dissolved electrolytes which the body contains. In this study the premise is used that a withdrawal of the electrolytes of the body fluids will be accompanied by a proportionate reduction of the volume of body water and that this change can only be repaired by replacing both the lost water and the lost electrolytes.

The relative structural importance of each of the electrolytes in blood plasma is indicated by the diagram in figure 1 , which presents

${ }^{1}$ Cooper Travelling Fellow of McGill University. 
their average normal concentrations in terms of acid-base equivalence. ${ }^{2}$ As may be seen $\mathrm{Na}$. constitutes nearly all of the plasma base and $\mathrm{Cl}^{\prime}$ is the chief factor on the acid side. The acid-base balance of this structure is preserved by the immediate and automatic adjust-

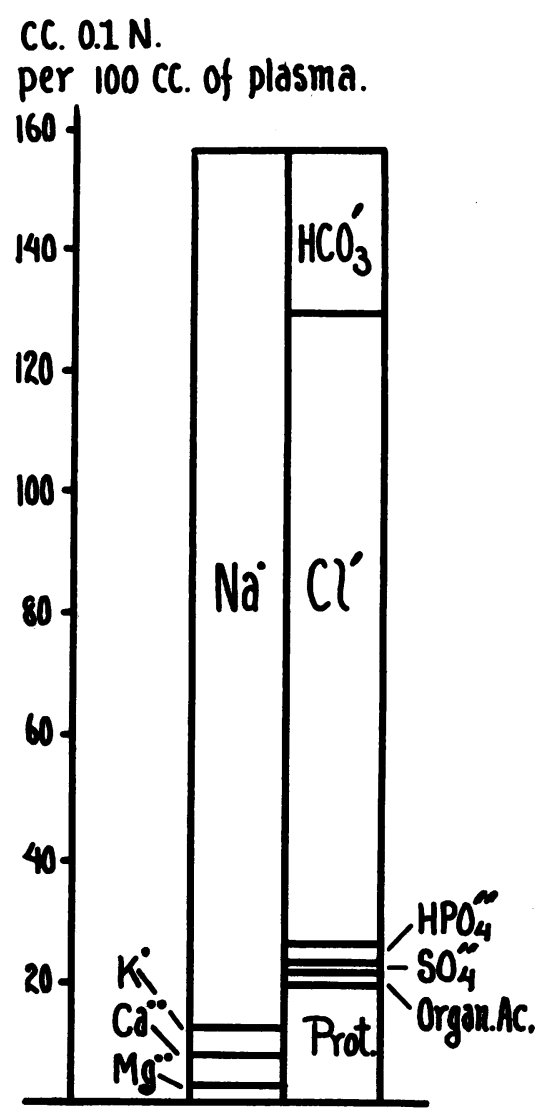

Fig. 1. Representing the Structural Factors of Normal Human Blood Plasma in Terms of Acid-base Equivalence at Ph 7.4

The factors are superimposed; those of base in the left hand, and those of acid in the right hand column.

${ }^{2}$ In this diagram the plasma salts are represented as completely dissociated. In order to simplify discussion of the interrelationship of the structural factors in the plasma, the presence of relatively very small concentrations of molecules is ignored and the plasma structure is regarded as composed of separately determined concentrations of ions. 
ment of $\left(\mathrm{HCO}_{3}^{\prime}\right)$ in the presence of a change in any of the other factors. Owing to this capacity of $\left(\mathrm{HCO}_{3}^{\prime}\right)$ for varying readily the total ionic concentration in the plasma, is determined by the concentration of the base. From these statements it may be deduced that a withdrawal of $\mathrm{Cl}^{\prime}$ from the plasma will be replaced by an increase of $\left(\mathrm{HCO}_{3}^{\prime}\right)$ and will therefore not cause a reduction of the total concentration of ions. A loss of $\mathrm{Na}^{\circ}$ however is not so readily replacable and moreover also involves a loss of its equivalence of $\mathrm{HCO}_{3}^{\prime}$. Loss of $\mathrm{Cl}^{\prime}$ thus does not deplete the ionic content of the plasma, whereas loss of $\mathrm{Na}^{\cdot}$ does and doubly. This point is presented here for the reason that a chief purpose of this study is to demonstrate that a loss of $\mathrm{Na}^{\circ}$ from the body is the essential factor in the rapid dehydration which follows obstruction of the pylorus.

TABLE 1

Measurements from blood serum samples, experiment I

\begin{tabular}{|c|c|c|c|c|c|}
\hline Number & Taken & Chloride & Bicarbonate & Urea & Protein \\
\hline & & $\underset{\text { per liter }}{\text { gram } \mathrm{NaCl}}$ & ool. per cent & $\begin{array}{l}m g . \text { per } \\
100 \text { cc. }\end{array}$ & per cent \\
\hline 1 & Before operation & 6.13 & 51.9 & 19 & 7.9 \\
\hline 2 & 18 hours after operation & 5.40 & 82.5 & 15 & 9.6 \\
\hline 3 & 29 hours after operation & 4.73 & 82.4 & 24 & 9.9 \\
\hline 4 & 42 hours after operation & 3.93 & 72.1 & 54 & 11.3 \\
\hline
\end{tabular}

Following pyloric closure, $\left(\mathrm{Cl}^{\prime}\right)$ in the plasma is reduced to a greater extent than $\left(\mathrm{Na}^{\circ}\right)$. If these defects in the ionic structure are correctly repaired by the introduction of $\mathrm{NaCl}$ into the body, more of $\mathrm{Cl}^{\prime}$ than of $\mathrm{Na} \cdot$ must be retained. Data were obtained from urine specimens collected during a period of $\mathrm{NaCl}$ administration which illustrate the adjustments used in defense of $\left(\mathrm{Cl}^{\prime}\right)$ in the body fluids in the presence of an excess of $\mathrm{Na}^{\circ}$ presenting for excretion in urine.

\section{EXPERIMENTAL}

\section{Experiment I}

Protocol: Male dog. Weight 17.3 kilos. Under ether anesthesia the stomach was severed just above pylorus and closed by means of a purse string suture. The proximal end of the duodenum was closed in the same way. The abdominal wound was strongly stitched and protected by means of a gauze and collodion dressing. The dog was permitted to drink water freely. Moderate but definite muscular 
twitchings were observed beginning about 16 hours after the operation. No convulsions were seen. The animal became very dull and feeble about 40 hours after the operation, and 10 hours later was found dead.

In table 1 are given measurements of bicarbonate, chloride, urea, and protein in samples of blood serum obtained before and at intervals following the operation. The measurements illustrate the changes which have been found $(3,4,5)$ to follow characteristically experimental closure of the pylorus. As may be seen, there occurs a large reduction of plasma chloride, an event readily explained as due to a withdrawal of $\mathrm{Cl}^{\prime}$ from the body in consequence of a continued vomiting of gastric secretions. The fall in plasma chloride it will be noted is accompanied by a rise in bicarbonate. Another outstanding change is a rapid and extensive dehydration of the plasma indicated by a progressive increase in the concentration of protein. A moderate impairment of renal function shown by a rise in the urea content of the plasma may reasonably be referred to the lack of water intake, there being practically no absorption of the water taken into the stomach.

TABLE 2

Measurements of chloride and bicarbonate given in table 1 compared in terms of tenth normal solutions

\begin{tabular}{|c|c|c|c|c|}
\hline & $\begin{array}{c}\text { Sample } \\
\text { No. } 1\end{array}$ & $\begin{array}{l}\text { Sample } \\
\text { No. } 2\end{array}$ & $\begin{array}{l}\text { Sample } \\
\text { No. } 3\end{array}$ & $\begin{array}{c}\text { Sample } \\
\text { No. } 4\end{array}$ \\
\hline $\mathrm{BCl}$, cc. $0.1 \mathrm{~N}$ per $100 \mathrm{cc} . \ldots \ldots \ldots$ & 106 & 93 & 82 & 68 \\
\hline $\mathrm{BHCO}_{8}$, cc. $0.1 \mathrm{~N}$ per $100 \mathrm{cc} . .$. & 23 & 37 & 37 & 32 \\
\hline $\mathrm{BCl}+\mathrm{BHCO}_{3}, 0.1 \mathrm{~N}$ per $100 \mathrm{cc} . . \ldots \ldots$ & 129 & 130 & 119 & 100 \\
\hline
\end{tabular}

A relationship of the chloride reduction and bicarbonate increase is shown by placing in table 2 the measurements of these two values expressed in equivalent terms, viz., as cubic centimeter of tenth normal solutions per $100 \mathrm{cc}$. of plasma. If the concentration of fixed base in the plasma remains stationary a reduction of $\left(\mathrm{Cl}^{\prime}\right)$ may be expected to produce an equivalent extension of $\left(\mathrm{HCO}_{3}{ }^{\prime}\right)$. That is, base released by $\mathrm{Cl}^{\prime}$ will be immediately balanced by $\mathrm{HCO}_{3}^{\prime}$ derived from the free carbonic acid in the plasma and this in turn replenished from the $\mathrm{CO}_{2}$ production in the body. As may be seen in the table, $\left(\mathrm{Cl}^{\prime}\right)+\left(\mathrm{HCO}_{3}{ }^{\prime}\right)$ is almost the same before and 18 hours after operation. However, 29 
hours and 42 hours after closure of the pylorus $\left(\mathrm{Cl}^{\prime}\right)+\left(\mathrm{HCO}_{3}^{\prime}\right)$ is found to be less then the initial sum of these values, indicating that extension of $\left(\mathrm{HCO}_{3}{ }^{\prime}\right)$ is less than the lowering of $\left(\mathrm{Cl}^{\prime}\right)$. This lack of full replacement of $\mathrm{Cl}^{\prime}$ by $\mathrm{HCO}_{3}{ }^{\prime}$ suggests a loss of fixed base from the plasma. That this occurs following experimental obstruction of the pylorus has been thoroughly shown by Hastings, Murray and Murray (6), and in our subsequent experiments.

\section{Experiment II}

Protocol: Small male dog. Weight before operation and after 12 hours of fasting 5.71 kilos. Abdomen opened under ether anesthesia and pylorus closed by ligature. Wound closed and protected as in first experiment. Five injections of sterile and warmed 5 per cent glucose solution into the peritoneal cavity, each of 250 cc., were given 16, 27, 40, 51 and 62 hours after operation. Blood samples were taken from 4 to 7 hours after glucose injections. The dog became rapidly weak and apathetic during the early part of the third day of the experiment, a few hours later began to have convulsions and from then until death 72 hours after operation was almost constantly in a state of clonic rigidity. Weight after death 5.20 kilos. -

The measurements of plasma values obtained during this experiment are given in table 3. Those of protein indicate marked dehydration of the plasma, though apparently not so extensive as in experiment I. Comparing the chloride values in tables 3 and 1 , the rate of reduction is seen to be approximately the same. Table 3 also contains measurements of sodium and these show a progressive loss of this structurally most important electrolyte of the plasma. In spite of $1250 \mathrm{cc}$. of water administered to this animal weighing only 5710 grams, there occurred during three days a loss in body weight of 500 grams. These data will serve to illustrate the. inefficacy of water alone to sustain the usual volume of the body fluids in the presence of a continued withdrawal of their chief structural components. It has been thoroughly shown by Haden and Orr (7) that the survival period in dogs, following pyloric or upper intestinal obstruction, cannot be appreciably if at all prolonged by subcutaneous injections of distilled water or of glucose solutions.

An analysis of the relationship of the changes in $\left(\mathrm{Cl}^{\prime}\right),\left(\mathrm{HCO}_{3}{ }^{\prime}\right)$ and $\left(\mathrm{Na}^{\circ}\right)$ is given in table 4 , the measurements in Table 3 being here presented as cubic centimeters $0.1 \mathrm{~N}$ per $100 \mathrm{cc}$. of plasma. The pro- 
gressive decrease in the values for $\left(\mathrm{Cl}^{\prime}\right)+\left(\mathrm{HCO}_{3}{ }^{\prime}\right)$ shows the diminution of chloride to be increasingly greater than the accompanying increase of bicarbonate. It was suggested above (experiment $\mathrm{I}$ ) that this incomplete replacement of loss of $\left(\mathrm{Cl}^{\prime}\right)$ by increase of $\left(\mathrm{HCO}_{3}{ }^{\prime}\right)$ is probably due to a depletion of plasma base. The measurements of $\left(\mathrm{Na}^{\circ}\right)$, which constitutes more than 90 per cent of the total fixed base in blood

TABLE 3

Measurements from blood serum samples, experiment II

\begin{tabular}{|c|c|c|c|c|c|c|}
\hline Number & Taken & Chloride & $\begin{array}{l}\text { Bicarbo- } \\
\text { nate }\end{array}$ & Sodium & $\begin{array}{l}\text { Phos- } \\
\text { phorus }\end{array}$ & Protein \\
\hline & & $\begin{array}{c}\text { grams } \mathrm{NaCl} \\
\text { per liter }\end{array}$ & ool. per cent & $\begin{array}{l}\text { mg. per } \\
100 \text { cc. }\end{array}$ & $\begin{array}{l}\text { mg. per } \\
100 \text { cc. }\end{array}$ & per cent \\
\hline 1 & Before operation & 6.53 & 58.9 & 337 & 7 & 6.9 \\
\hline 2 & 23 hours after operation & 5.07 & 60.7 & 315 & & 8.6 \\
\hline 3 & 45 hours after operation & 3.80 & 73.9 & 294 & 12 & 8.8 \\
\hline $4^{*}$ & 66 hours after operation & 2.40 & 80.7 & 281 & 14 & 8.2 \\
\hline
\end{tabular}

* Ketone acids, 0.28 gram (as B. oxybutynic) per liter.

TABLE 4

Measurements of chloride, bicarbonate and sodium given in table 3 compared in terms of tenth normal solutions

\begin{tabular}{|c|c|c|c|c|}
\hline & $\begin{array}{l}\text { Sample } \\
\text { No. } 1\end{array}$ & $\begin{array}{c}\text { Sample } \\
\text { No. } 2\end{array}$ & $\begin{array}{l}\text { Sample } \\
\text { No. } 3\end{array}$ & $\begin{array}{l}\text { Sample } \\
\text { No. } 4\end{array}$ \\
\hline $\begin{array}{l}\mathrm{BCl} \text {, cc. } 0.1 \mathrm{~N} \text { per } 100 \mathrm{cc} \ldots \ldots \ldots \ldots \ldots \ldots \ldots \ldots \ldots \\
\mathrm{BHCO}_{3}, \text { cc. } 0.1 \mathrm{~N} \text { per } 100 \mathrm{cc} \ldots \ldots \ldots \ldots \ldots \ldots \ldots \ldots\end{array}$ & $\begin{array}{r}113 \\
26\end{array}$ & $\begin{array}{l}87 \\
27\end{array}$ & $\begin{array}{l}66 \\
33\end{array}$ & $\begin{array}{l}41 \\
36\end{array}$ \\
\hline $\mathrm{BCl}+\mathrm{BHCO}_{3}$, cc. $0.1 \mathrm{~N}$ per $100 \mathrm{cc} . \ldots \ldots \ldots \ldots \ldots$ & 139 & 114 & 99 & 77 \\
\hline $\begin{array}{l}\mathrm{Na}, \mathrm{cc} .0 .1 \mathrm{~N} \text { per } 100 \mathrm{cc} . \ldots \ldots \ldots \ldots \ldots \ldots \ldots \ldots \\
\mathrm{BCl}+\mathrm{BHCO}_{3}, \text { cc. } 0.1 \mathrm{~N} \text { per } 100 \mathrm{cc} . . \ldots \ldots \ldots \ldots \ldots\end{array}$ & $\begin{array}{l}146 \\
139\end{array}$ & $\begin{array}{l}137 \\
114\end{array}$ & $\begin{array}{r}128 \\
99\end{array}$ & $\begin{array}{r}122 \\
77\end{array}$ \\
\hline $\mathrm{Na}-\left(\mathrm{BCl}+\mathrm{BHCO}_{3}\right)$, cc. $0.1 \mathrm{~N}$ per $100 \mathrm{cc}$. & 7 & 23 & 29 & 45 \\
\hline
\end{tabular}

plasma, show a progressive reduction in its concentration. Subtracting, however, the values for $\left(\mathrm{Cl}^{\prime}\right)+\left(\mathrm{HCO}_{3}{ }^{\prime}\right)$ from those for $\left(\mathrm{Na}^{\circ}\right)$, remainders are obtained which are progressively larger (see table 3). It is thus apparent that besides a loss of sodium from the plasma some other factor is concerned in preventing the increase of bicarbonate from corresponding with the reduction of chloride.

To illustrate further and explain the finding that bicarbonate increase is much less than would be the case were decrease in $\left(\mathrm{Cl}^{\prime}\right)$ 
the only factor determining $\left(\mathrm{HCO}_{3}{ }^{\prime}\right)$, the measurements given in table 4 are presented graphically by means of the diagrams in figure 2 . The left hand column represents the sodium concentration plus the usual average value for the sum of the other three plasma bases,

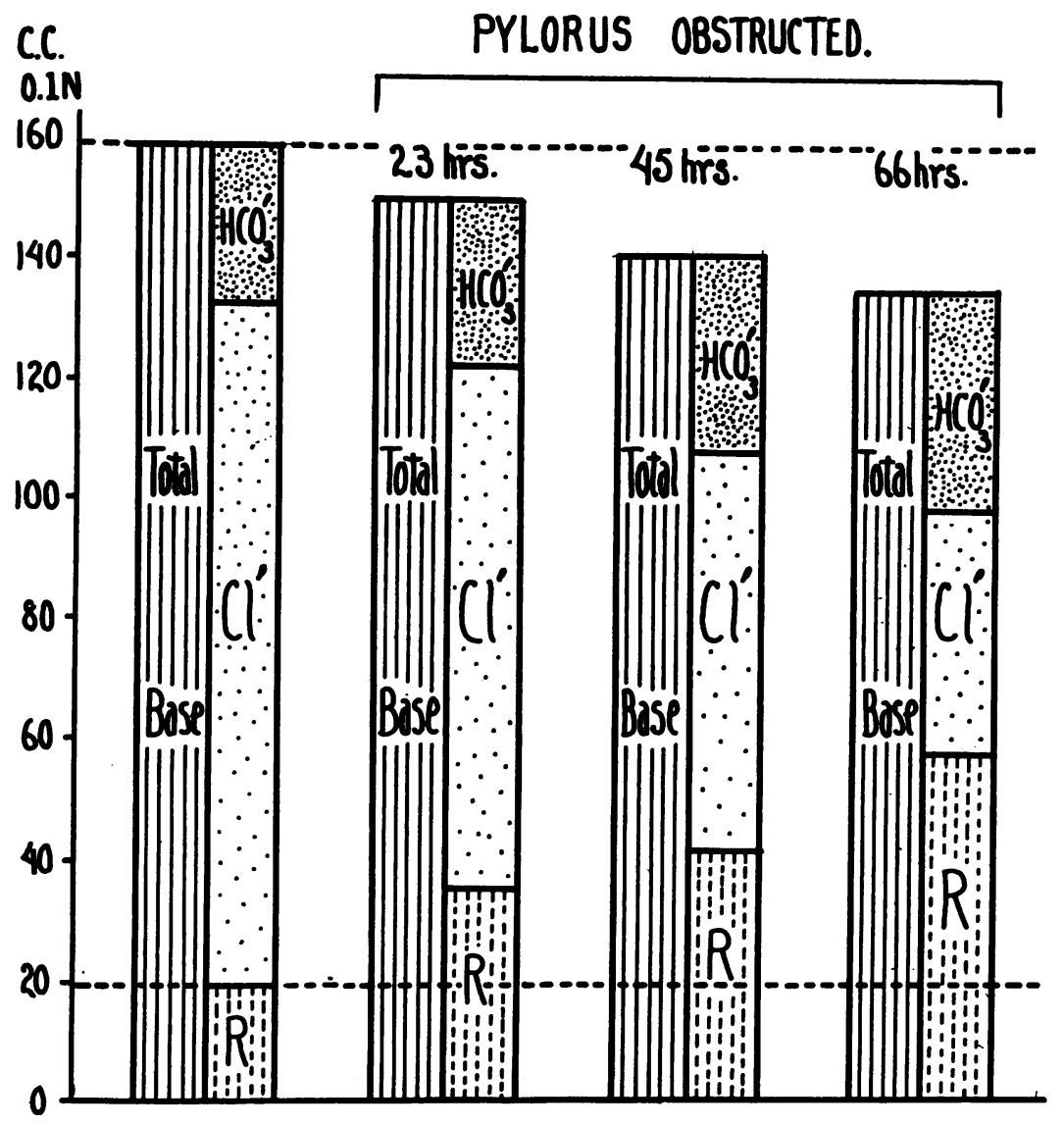

Fig. 2. Diagrams Constructed from Measurements Given in Table 4, Illustrating Factors Determining the Bicarbonate Concentration

potassium, calcium, and magnesium, taken as $12 \mathrm{cc} .0 .1 \mathrm{~N}$ per $100 \mathrm{cc}$. of plasma. On the right side of the diagram is given first the $\left(\mathrm{HCO}_{3}{ }^{\prime}\right)$ and then the $\left(\mathrm{Cl}^{\prime}\right)$ measurement. The remainder of the base column is balanced (see figure 1), by the relatively small concentrations of 
$\mathrm{HPO}_{4}{ }^{\prime \prime}, \mathrm{SO}_{4}{ }^{\prime \prime}$, organic acids and the base equivalence of the plasma proteins. These factors, except in the case of $\mathrm{HPO}_{4}{ }^{\prime \prime}$, were not measured and their sum is designated $R$ in the diagrams. It is at once apparent in figure 2 that there occurs a large and progressive increase of $R$ and that this change exerts quite as large a limitation of the increase of $\left(\mathrm{HCO}_{3}{ }^{\prime}\right)$ which tends to follow recession of $\left(\mathrm{Cl}^{\prime}\right)$ as does the loss of sodium. The broken lines across the diagrams indicate the extent to which reduction of base and increase of $R$ respectively limit $\left(\mathrm{HCO}_{3}{ }^{\prime}\right)$. It will be clearly apparent from the diagrams that an enormous concentration of bicarbonate would result from the depletion of $\left(\mathrm{Cl}^{\prime}\right)$ were it not to a large extent prevented by these two changes in the acid-base balance of the plasma. From the data in table 4 it may be computed that, if $\left(\mathrm{Cl}^{\prime}\right)+\left(\mathrm{HCO}_{3}{ }^{\prime}\right)$ had remained in the plasma at the initial value, $139 \mathrm{cc} .0 .1 \mathrm{~N}$ per $100 \mathrm{cc}$., then $\left(\mathrm{HCO}_{3}{ }^{\prime}\right)$ in sample no. 4 would have been 98 instead of $36 \mathrm{cc} .0 .1 \mathrm{~N}$ per $100 \mathrm{cc}$, or, in the more familiar form of statement, 203 instead of 81 volumes per cent of $\mathrm{CO}_{2}$. Considering the possibility for bicarbonate increase represented by the very large reduction of chloride, the actual degree of alkalosis usually found following pyloric obstruction is, owing to these opposing factors, relatively small.

Explanation of this increase in $R$ is not supplied by these data. The several measurements of phosphorus given in table 3 show that $\left(\mathrm{HPO}_{4}{ }^{\prime \prime}\right)$, one of the factors in $R$, was double its usual value in sample no. 4. But this factor is in the first instance so small (see figure 1) that this large relative increase explains to only a slight extent the total increase of $R$. Increase of the usually even smaller concentration of $\mathrm{SO}_{4}{ }^{\prime \prime}$ to an extent appreciably altering $R$ seems improbable. The usual value for the concentration of organic acid radicals en route for excretion is not accurately known. The single measurement of ketone acids obtained from sample no. 4 and given in table 4 indicates that there was no accumulation of these acids and indeed such accumulation would scarcely be possible following the administration of glucose solution. The most probable explanation of a considerable part of the increase of $R$ is an increase of the base equivalence of the plasma proteins due both to the absolute increase in their concentration and to a shift presumably, in consequence of the bicarbonate 
increase, of the reaction of the plasma in the direction of alkalinity. ${ }^{3}$ The extension of $R$ is, however, so large that it does not seem probable that it can be entirely referred to an increase of base balanced by protein. There is thus suggested an increased concentration of organic acids.

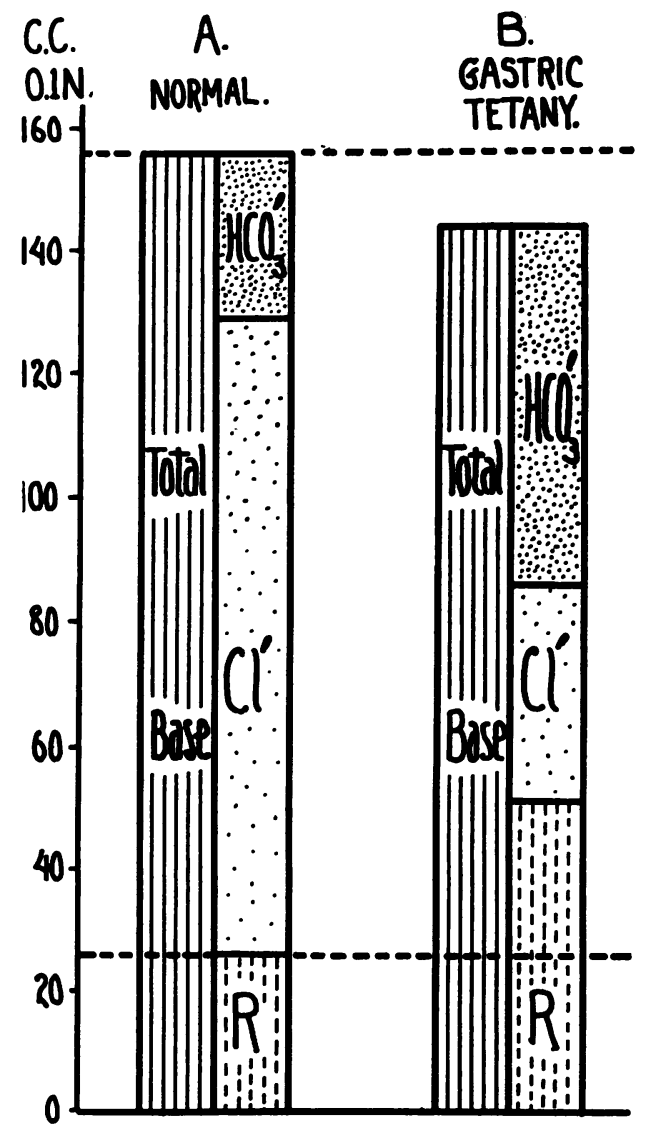

Fig. 3. Showing Relationship to Bicarbonate Concentration of Large Changes in Plasma factors Found in a Case of Severe Gastric Tetany

${ }^{3}$ The extent of the increase in plasma alkalinity following experimental pyloric obstruction in dogs is, according to the $\mathrm{pH}$ measurements published by Hastings, Murray and Murray (6), surprisingly small, even in the presence of a very large increase of bicarbonate. 
To illustrate further the perhaps obvious point that the alkalosis which may follow obstruction of the pylorus is a consequence of the loss of $\mathrm{Cl}^{\prime}$ from the plasma and to show again that extension of $\left(\mathrm{HCO}_{3}{ }^{\prime}\right)$ from this cause is limited by loss of plasma base and by increase in some factor, or factors, contained in $R$, the diagrams in figure 3 were plotted: $(a)$, from average values obtaining in normal human plasma and $(b)$, from values found in a sample of blood serum taken from a young man presenting severe symptoms of tetany following nearly complete pyloric obstruction caused by gastric ulcer. ${ }^{4}$ Here the increase in bicarbonate following the huge loss of chloride is much greater than was found in the experiments cited above, but is nevertheless considerably limited by loss of $\mathrm{Na}^{\circ}$ and increase in $R$. Were all of the chloride loss replaced by bicarbonate the latter would be considerably greater (213 volumes per cent of $\mathrm{CO}_{2}$ ) than the very large value (130 volumes per cent of $\mathrm{CO}_{2}$ ) which was actually found.

\section{Experiment III}

Protocol: Female dog. Weight 10.20 kilos. Abdomen opened under ether anesthesia and pylorus closed by tying with heavy silk. Operation wound then closed and protected as in preceding experiments. Beginning 24 hours after operation, four injections of sterile and warm 0.9 per cent sodium chloride solution, each of $400 \mathrm{cc}$., were given into, the peritoneal cavity, the first three at 6-hour intervals and the last one after a 12-hour interval, i.e., $1600 \mathrm{cc}$. of the sodium chloride solution were given during the first 48 hours following operation. Beginning 96 hours (4 days) after the operation, three injections of sterile and warm 0.82 per cent ammonium chloride solution, each of $400 \mathrm{cc}$., were given into the peritoneal cavity at 6-hour intervals. The dog was permitted to drink distilled water to such extent as desired. Throughout the experiment it was kept in a metabolism cage and the large amounts of water containing gastric secretions which were vomited were collected over successive 24 -hour periods. The stomach was not emptied by tube at the end of each of these periods so that the collections per 24 hours were only approximate. Urine was obtained by catheter during the first 5 days of the experiment at approximately 12-hour intervals. It is believed that the collection of urine over this period was complete. The dog during the 24 -hour period of sodium chloride injections and for 2 days thereafter was bright and lively and apparently entirely comfortable, then gradually became dull and weak. The injections of ammonium chloride solution produced no arrest of the increasing

${ }^{4}$ The data used in constructing this diagram has been published by one of us (Ross) in a paper discussing the pathogenesis of gastric tetany (8). 
apathy and feebleness. Twelve hours after the last injection and $6 \frac{1}{2}$ days after the operation the animal was killed with ether.

This experiment was undertaken with the purpose of testing the probability that the lowering of plasma base following pyloric obstruction is due to a loss of base as well as of chloride in the vomitus and also to demonstrate that introduction into the body, of $\mathrm{NaCl}$ solution, because it supplies both of the depleted ions will tend to restore the volume of body fluids, whereas administration of water containing a salt, $\mathrm{NH}_{4} \mathrm{Cl}$, which provides only chloride, will not check dehydration. The much greater structural significance of $\left(\mathrm{Na}^{\circ}\right)$ than of $\left(\mathrm{Cl}^{\prime}\right)$ has been discussed above. The urine specimens were collected for the purpose of obtaining data indicating the ability of the body to sepa-

TABLE 5

Measurements from vomitus, experiment III

\begin{tabular}{|c|c|c|c|c|c|c|c|}
\hline 24-hour periods & $\begin{array}{l}\text { Water } \\
\text { drunk }\end{array}$ & Vomitus & $\mathrm{pH}$ & $\mathrm{Cl}^{\prime}$ & $\mathrm{Na} \cdot$ & $\mathbf{K} \cdot$ & Protein \\
\hline & $c c$. & $c c$. & & $c c .0 .1 \mathrm{~N}$ & cc. $0.1 \mathrm{~N}$ & cc. $0.1 \mathrm{~N}$ & grams \\
\hline 1 & 2,100 & 1,970 & 4.5 & 504 & 289 & 0 & 0 \\
\hline $2^{*}$ & 1,500 & 1,430 & 2.1 & 524 & 212 & 0 & 0 \\
\hline 3 & 130 & 570 & 1.5 & 672 & 233 & 44 & 2.4 \\
\hline 4 & 500 & 660 & 2.4 & 660 & 360 & 39 & 3.6 \\
\hline 5 & 1,070 & 1,250 & 7.9 & 916 & 565 & 82 & 11.4 \\
\hline Totals. & 5,300 & 5,880 & & 3,276 & 1,659 & 165 & \\
\hline
\end{tabular}

$* 1600$ cc. 0.9 per cent $\mathrm{NaCl}$ solution ( $=2480 \mathrm{cc} .0 .1 \mathrm{~N}$ ) injected into the peritoneal cavity during this period.

rately and correctly retain $\left(\mathrm{Na}^{\circ}\right)$ and $\left(\mathrm{Cl}^{\prime}\right)$ in the body fluids from the administered $\mathrm{NaCl}$.

In table 5 are given data obtained from five consecutive 24-hour collections of the vomitus which the animal provided after drinking the copious amounts of water. The collections during the remaining one and one-half days of the experiment were contaminated with urine and for this reason were not analyzed. That there occurs a very considerable amount of $\mathrm{Na}{ }^{\circ}$ as well as of $\mathrm{Cl}^{\prime}$ in the vomited stomach secretions may be seen at once in the table. In all except one of the specimens $\mathrm{Na}^{\circ}$ was found to an extent of somewhat more than half the 
equivalence of the $\mathrm{Cl}^{\prime}$ loss. ${ }^{5}$ During the fifth day of the experiment the dog began to grow dull and feeble after having been until then bright and lively. The total of $\mathrm{Cl}^{\prime}$ lost from the body in stomach secretions during the first four days of the experiment was, according to the measurements in table $5,2300 \mathrm{cc} .0 .1 \mathrm{~N}$ which is approximately the amount $(2480 \mathrm{cc} .0 .1 \mathrm{~N})$ introduced into the body during the second day. The estimations of fixed base excretion in the urine given in Table 7 make evident a large removal of $\mathrm{Na}^{\circ}$ by way of the kidney immediately following the injections of $\mathrm{NaCl}$ solution in addi-

TABLE 6

Measurements from blood serum samples, experiment III

\begin{tabular}{|c|c|c|c|c|c|c|c|}
\hline Time of taking sample & $\begin{array}{l}\text { Bicarbo- } \\
\text { nate }\end{array}$ & Chloride & Sodium & Calcium & $\begin{array}{l}\text { Phos- } \\
\text { phorus }\end{array}$ & Protein & $\begin{array}{c}\text { Body } \\
\text { weight }\end{array}$ \\
\hline & $\left|\begin{array}{c}\text { vol. per cent } \\
\mathrm{CO}_{2}\end{array}\right|$ & $\begin{array}{c}\text { grams } \mathrm{NaCl} \\
\text { per liter }\end{array}$ & $\begin{array}{l}\text { mg. per } \\
100 \text { cc. }\end{array}$ & $\begin{array}{c}\text { mg. per } \\
100 \text { cc. }\end{array}$ & $\begin{array}{l}\text { mg. per } \\
100 \text { cc. }\end{array}$ & per cent & kilos \\
\hline Before operation. & 47.0 & 5.99 & & 11.0 & 5.8 & 7.0 . & 10.20 \\
\hline 1 day after operation. & 61.6 & 4.90 & & 11.5 & 5.6 & 9.3 & 9.97 \\
\hline 2 days after operation*. & 69.0 & 5.30 & 324 & 10.0 & 4.0 & 6.7 & 10.50 \\
\hline 3 days after operation. . & 70.0 & 5.67 & 310 & 9.8 & 5.8 & 6.4 & 10.18 \\
\hline 4 days after operation. & 73.6 & 5.27 & 305 & & 4.8 & 6.8 & 9.76 \\
\hline 5 days after operation. . & 81.0 & 4.29 & 280 & 10.3 & & 7.9 & 9.12 \\
\hline 6 days after operation $\dagger \ldots$. & 44.3 & 4.70 & 294 & 10.4 & 11.0 & 8.9 & 8.94 \\
\hline $6 \frac{1}{2}$ days after operation....... & 56.0 & 4.33 & 274 & 11.9 & & 9.6 & 8.74 \\
\hline
\end{tabular}

* Taken 6 hours after completion of administration of $1600 \mathrm{cc} .0 .9 \mathrm{NaCl}$ solution.

$\dagger$ Taken 6 hours after completion of administration of 1200 cc. 0.82 per cent $\mathrm{NH}_{4} \mathrm{Cl}$ solution.

tion to the steady loss in the vomitus. The onset of symptoms during the fifth day, roughly indicate that by then the benefit of the $\mathrm{NaCl}$ solution injected during the second day was dissipated by subsequent loss of the replaced elements. The fifth day specimen was large, con-

${ }^{5}$ That is, the measurement of $\mathrm{HPO}_{4}{ }^{\prime \prime}$ is stated in terms of the base equivalence indicated by the $\mathrm{BH}_{2} \mathrm{PO}_{4}: \mathrm{B}_{2} \mathrm{HPO}_{4}$ ratio as determined by the $\mathrm{pH}$ of the specimen.

The base equivalence of the organic acid excretion was estimated by subtracting a calculated value for free organic acids. This was obtained by subtracting from a measurement of the titratable acidity of the specimen (to $\mathrm{pH} 7.4$ ) the amount of $\mathrm{BH}_{2} \mathrm{PO}_{4}$ in the specimen in excess of that which would obtain at $\mathrm{pH}$ 7.4, the data used here being the total $\mathrm{HPO}_{4}{ }^{\prime \prime}$ excretion and the phosphate ratio corresponding to the $\mathrm{pH}$ of the specimen.

The other acid radicals, $\mathrm{Cl}^{\prime}$ and $\mathrm{SO}_{4}{ }^{\prime \prime}$ carry, of course, their full equivalence of base into the urine. 
tained a much increased amount of $\mathrm{Na}^{\circ}$ and of $\mathrm{Cl}^{\prime}$ and curiously, instead of being strongly acid as were the preceding, was markedly alkaline ( $\mathrm{pH}$ 7.9). An appreciable amount of $\mathrm{K}^{\cdot}$ was found in this specimen but the total of $\left(\mathrm{Na}^{\circ}\right)+\left(\mathrm{K}^{\circ}\right)$ was far short of the $\left(\mathrm{Cl}^{\prime}\right)$ measurement. This specimen was moreover strikingly different in appearance from the preceding ones, being straw colored instead of presenting a faint whitish opalescence. It was also found to contain a large amount of protein (11.4 grams.) and to this constituent may probably be referred the obliteration of $\mathrm{HCl}$ acidity.

The extent to which isotonic solutions of $\mathrm{NaCl}$ and of $\mathrm{NH}_{4} \mathrm{Cl}$ respectively tend to support a normal composition of the blood plasma is indicated by the measurements of plasma values given in table 6 . The attempts at measurement of $\left(\mathrm{Na}{ }^{\circ}\right)$ in the first two specimens were unfortunately failures. It is probable, however, that some degree of depletion of $\left(\mathrm{Na}^{\circ}\right)$ had occurred during the 24 hours following operation. At any rate, following the injections of sodium chloride solution during the second day of the experiment, plasma $\left(\mathrm{Na}^{\circ}\right)$ was found to be $324 \mathrm{mg}$. per $100 \mathrm{cc}$. which is approximately its normal value and with which may be compared the measurement of $294 \mathrm{mg}$. found at the same interval after operation in experiment II. The value of the injections of $\mathrm{NaCl}$ solution in restoring the water content of the body is well shown by the measurements of plasma protein and also by those of body weight. Benefit from the injections was strikingly apparent in the behavior of the animal. For two days following them, it was as bright and lively as a normal animal. Relief of thirst during these two days was indicated by the relatively small amount of water drunk.

During the fifth day there occurred a large reduction of plasma $\left(\mathrm{Na}^{\circ}\right)$ and $\left(\mathrm{Cl}^{\prime}\right)$ and a large increase in protein. As has been mentioned, the animal began to grow weak and dull. A marked increase in thirst was also evident. The injections of $\mathrm{NH}_{4} \mathrm{Cl}$ solution were given during the next 24 hours. These entirely failed to arrest the increasing feebleness and apathy of the animal. As may be seen in table 6, the changes destroying the normal composition of the plasma continued. In spite of the $1200 \mathrm{cc}$. of water given, dehydration of the plasma as indicated by the protein measurement, increased. This large amount of water was eliminated so rapidly that, during the 24 hours that it 
was given, there occurred an actual loss of body weight. Following the first injection of $\mathrm{NH}_{4} \mathrm{Cl}$ solution, urination became so frequent that separate collection of urine (by catheter) and vomitus was abandoned. In the last sample of serum obtained, owing to the increase in protein and $\left(\mathrm{Cl}^{\prime}\right)$ and the fall in $(\mathrm{Na} \cdot),\left(\mathrm{HCO}_{3}{ }^{\prime}\right)$ was greatly reduced.

Measurements of calcium and phosphorus were made in most of the serum samples. Except for a relatively large increase in phosphorus in the sample obtained following administration of $\mathrm{NH}_{4} \mathrm{Cl}$, the values found for these factors were nearly stationary.

It is evident from these data that, although $\mathrm{NH}_{4} \mathrm{Cl}$ may be expected to restore the loss of $\left(\mathrm{Cl}^{\prime}\right)$ the other disastrous alterations of

TABLE 7

Measurements of acid and base factors in urine, experiment III

\begin{tabular}{|c|c|c|c|c|c|c|c|c|c|c|c|}
\hline \multirow{2}{*}{$\begin{array}{l}\text { 12-hour } \\
\text { specimens }\end{array}$} & \multirow{2}{*}{$\begin{array}{l}\text { Vol- } \\
\text { ume }\end{array}$} & \multirow{2}{*}{$\mathrm{pH}$} & \multicolumn{6}{|c|}{$\begin{array}{l}\text { Acid excretion in terms of base } \\
\text { bound in urine }\end{array}$} & \multirow{2}{*}{$\mathrm{NH}_{4}$} & \multirow{2}{*}{$\begin{array}{c}\text { Fixed } \\
\text { base }\end{array}$} & \multirow{2}{*}{$\begin{array}{l}\text { Creati- } \\
\text { nine }\end{array}$} \\
\hline & & & $\begin{array}{c}\text { Organic } \\
\text { acids }\end{array}$ & HPO" & $\mathrm{SO}^{\prime \prime}$ & $\mathrm{Cl}^{\circ}$ & $\mathrm{HCO}_{3}^{\prime}$ & Total & & & \\
\hline & & & cc. $0.1 \mathrm{~N}$ & $c c .0 .1 \mathrm{~N}$ & $c c .0 .1 \mathrm{~N}$ & cc. $0.1 \mathrm{~N}$ & cc. $0.1 \mathrm{~N}$ & $c c .0 .1 \mathrm{~N}$ & $c c .0 .1 \mathrm{~N}$ & $c c .0 .1 \mathrm{~N}$ & $m g$. \\
\hline No. 1 & 58 & 6.6 & 68 & 120 & 94 & 44 & 3 & 329 & 78 & 251 & 190 \\
\hline No. 2 & 46 & 5.7 & 65 & 74 & 29 & 4 & 1 & 173 & 82 & 91 & 170 \\
\hline No. 3 & 75 & 6.3 & 69 & 99 & 56 & 10 & 2 & 236 & 116 & 120 & 180 \\
\hline No. $4^{*}$ & 240 & 7.9 & 97 & 170 & 32 & 10 & 352 & 661 & 10 & 651 & 130 \\
\hline No. 5 & 68 & 7.5 & 79 & 143 & 33 & 10 & 91 & 356 & 55 & 301 & 190 \\
\hline No. 6 & 70 & 6.6 & 48 & 57 & 48 & 3 & 4 & 160 & 33 & 127 & 140 \\
\hline No. 7 & 46 & 6.4 & 31 & 60 & 83 & 2 & 2 & 178 & 82 & 96 & 160 \\
\hline
\end{tabular}

* These two specimens were collected during period of administration of $1600 \mathrm{cc} .0 .9$ per cent $\mathrm{NaCl}$ solution.

plasma structure will continue and may in fact be aggravated by the diuretic action of this salt. It must be admitted that the animal was in a condition of much more serious disrepair when the effect of $\mathrm{NH}_{4} \mathrm{Cl}$ was tested than when $\mathrm{NaCl}$ was given. The character of the data obtained, however, clearly indicates the unsuitableness of $\mathrm{NH}_{4} \mathrm{Cl}$ as a reparative agent. It may also be mentioned that the introduction of $\mathrm{NH}_{4} \mathrm{Cl}$ solution into the peritoneal cavity was evidently irritating to a degree which should we believe, from the point of view of practical therapeutics, entirely forbid the giving of this salt by clysis.

There remains for brief discussion the data from consecutive 12-hour collections of urine covering the period of administration of $\mathrm{NaCl}$ 
solution. These are presented in table 7 for the purpose of showing the removal of the excess of $\mathrm{Na}^{\circ}$ over $\mathrm{Cl}^{\prime}$ presenting for excretion in the urine owing to the larger deficit of $\left(\mathrm{Cl}^{\prime}\right)$ than of $\left(\mathrm{Na}^{\circ}\right)$ within the body. The usual situation, an excess of acid over fixed base claiming excretion which is met chiefly by a regulated production of ammonia, is here reversed. The chief purpose of these data is to illustrate the fact that when fixed base claims excretion in the urine in excess of the sum of the acid radicals requiring removal, the body possesses in carbonic acid a substance which is abundantly and adjustably available in defense of other acid components of the body fluids. Gamble (9) has shown that owing to a stationary concentration of $\mathrm{H}_{2} \mathrm{CO}_{3}$ in the urine, the amount of base which can enter as bicarbonate is a function of the $\mathrm{pH}$ at which urine is produced. At the usual $\mathrm{pH}$ of urine it cannot contain an appreciable amount of bicarbonate, a fact which excellently suits the usual need for an economy of base in the process of acid excretion. Adjustment of urine $\mathrm{pH}$ in the direction of alkalinity produces a rapid increase in the amount of bicarbonate entering the urine. These circumstances permit the use of carbonic acid as a means of conserving other acid components of the body fluids in a manner quite analogous to the defense of fixed base which the regulated availability of ammonia provides. The acid as well as the base side of the ionic structure of the body fluids is thus protected by the presence of a factor in the construction of urine which is widely adjustable.

The measurements of the acid factors in the urine are given (table 7) in terms of base bound at the reaction of the urine specimen. ${ }^{5}$ The amount of fixed base in the urine is taken as the difference between the sum of the acid factors and the ammonia measurement. The collections as regards 12-hour intervals were not sharp. Their character in this respect is indicated by the creatinine measurements. As may be seen in the table, $\mathrm{Cl}^{\prime}$ is, except in the first specimen, permitted to enter the urine to only a very slight extent. Following the injections of $\mathrm{NaCl}$ solution there occurs a large but brief rise in the excretion of fixed base. This rise is seen to be chiefly balanced by an increase in $\mathrm{HCO}_{3}{ }^{\prime}$. The data are presented graphically in figure 4, and by way of further illustration the acid-base composition of the specimen (no. 4) containing most of the excess of base removed is represented by the diagram $\mathrm{A}$ in figure 5. Diagram $\mathrm{B}$ in this figure shows the compo- 


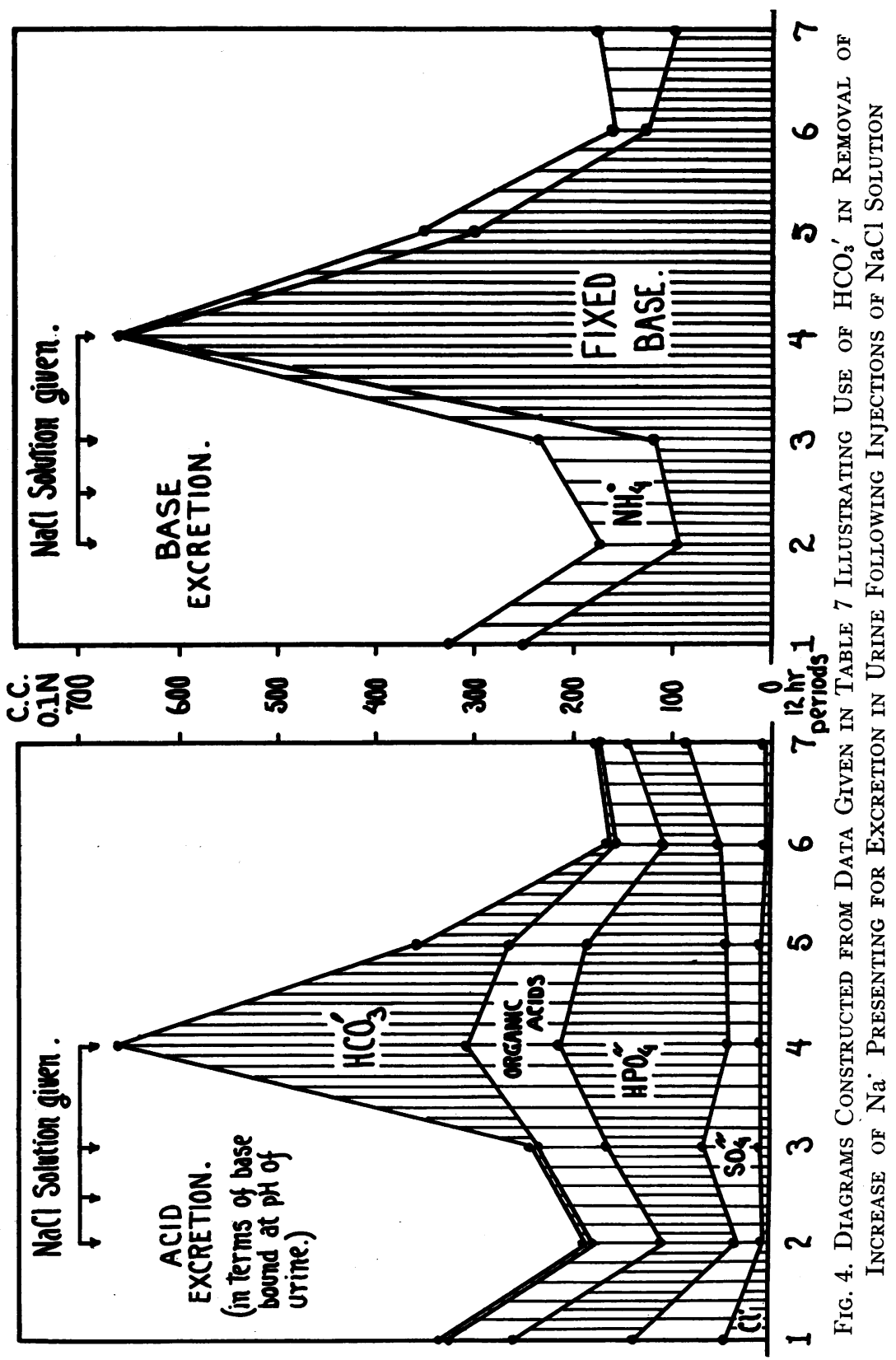


sition which might have been expected in this specimen had it been produced at the average usual reaction of urine, $\mathrm{pH}$ 6.0. At this $\mathrm{pH}$ only a negligible amount of base can be carried into the urine as

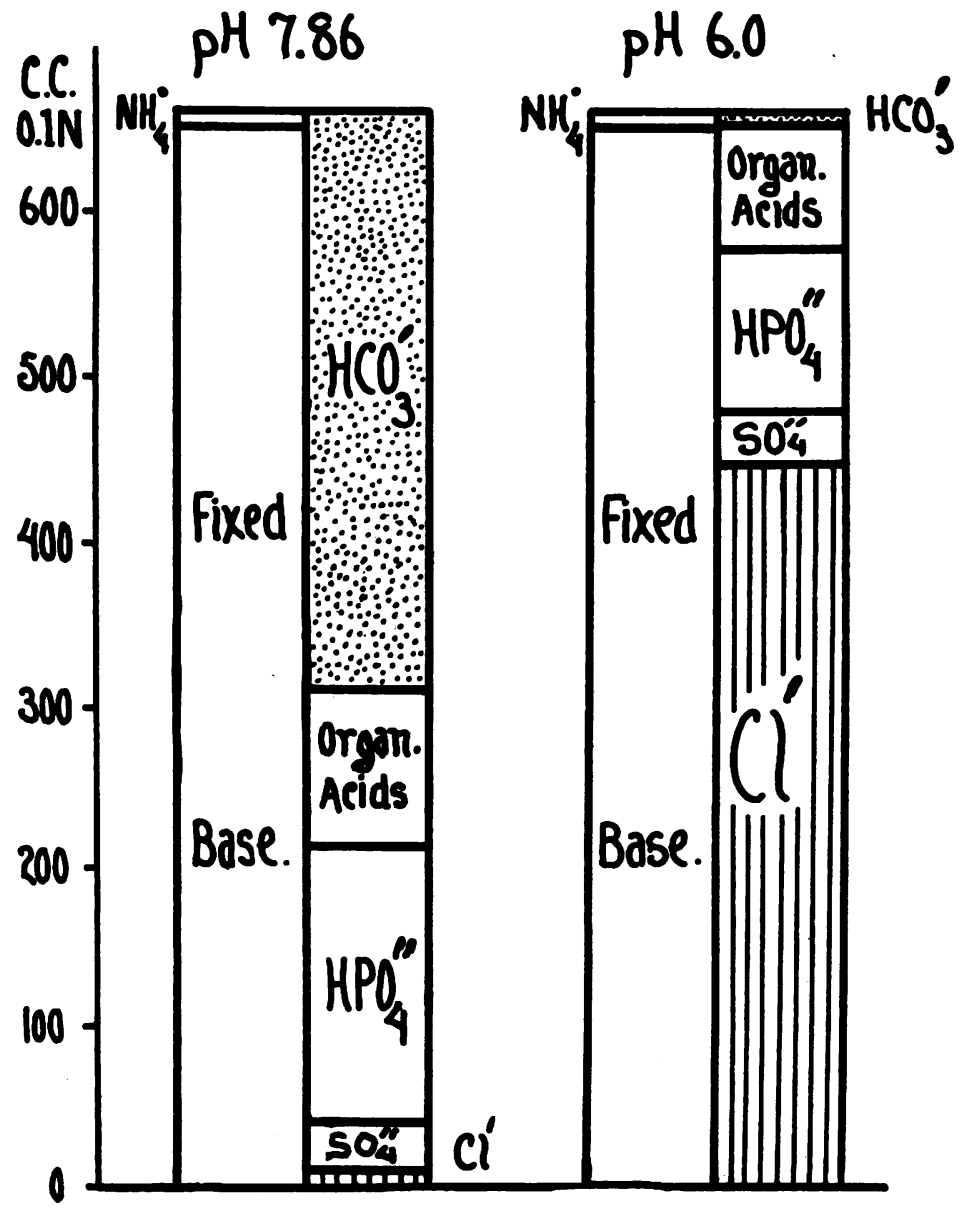

Fig. 5. Illustrating the Extent of Conservation of $\mathrm{Cl}^{\prime}$ Obtained by Production of Specimen No. 4 (Table 7) at pH 7.86 Instead of at the Usual Reaction of URine, pH 6.0

$\mathrm{BHCO}_{3}$ owing to the stationary value for the concentration of $\mathrm{H}_{2} \mathrm{CO}_{3}$ in urine. Furthermore, the base equivalence of the organic acids and that of $\mathrm{HPO}_{4}{ }^{\prime \prime}$ is considerably less than at $\mathrm{pH} 7.86$. The diagrams will serve to show clearly the magnitude of the changes in these 
factors referable to $\mathrm{pH}$ and the consequent large saving of $\mathrm{Cl}^{\prime}$ accomplished by the production of this specimen at $\mathrm{pH} 7.86$ instead of at the usual reaction of urine.

The secretion of an extremely alkaline urine following administration of this neutral salt clearly demonstrates the separate metabolism of its component ions.

\section{DISCUSSION}

It will be noted that we have used in this study the point of view that the failure of physiological processes and death following experimental obstruction of the pylorus may be reasonably regarded as referable to the continued reduction of the volume of the body fluids in consequence of a progressive demolition of their sustaining structure caused by the loss of $\mathrm{Cl}^{\prime}$ and more significantly of $\mathrm{Na}^{\circ}$ in vomited stomach secretions. The beneficial effect from introducing $\mathrm{Na}^{\circ}$ and $\mathrm{Cl}^{\prime}$ into the body along with water is therefore regarded as being due simply to repair of this structure permitting recovery of a normal volume of body water. The data from these few experiments accords satisfactorily with this view.

In 1912, Hartwell and Hoguet (10) showed that following duodenal obstruction a dog could be kept alive for several weeks by replacing the loss of body water with physiological salt solution. They believed that the effect of the salt solution consisted simply in preventing dehydration. MacCallum and his co-workers demonstrated that following pyloric obstruction in dogs, the fall in plasma $\left(\mathrm{Cl}^{\prime}\right)$ and the increase in $\left(\mathrm{HCO}_{3}{ }^{\prime}\right)$ with the accompanying symptoms of gastric tetany could be prevented by injections of isotonic $\mathrm{NaCl}$ solution.

Recently Haden and Orr $(5,11)$ have published extensive studies of plasma changes following experimental pyloric and upper intestinal obstruction. Their measurements show the large fall in chloride accompanied by more or less rise in bicarbonate and an increasing accumulation of the products of protein metabolism. They have tested the therapeutic efficacy of administration by clysis of a great number of salts: $\mathrm{KCl}, \mathrm{NH}_{4} \mathrm{Cl}, \mathrm{CaCl}_{2}, \mathrm{MgCl}_{2}, \mathrm{KI}, \mathrm{NaBr}, \mathrm{Na}_{2} \mathrm{SO}_{4}$, $\mathrm{MgSO}_{4}, \mathrm{NaH}_{2} \mathrm{PO}_{4}$, and $\mathrm{Na}_{2} \mathrm{HPO}_{4}$; and have found all of these to be of no benefit and, as is not surprising, often harmful (12). They have quite thoroughly demonstrated, however, that injection of $\mathrm{NaCl}$ solu- 
tion tends to restore normal plasma values and greatly prolong the life of the animal (7). The loss of $\mathrm{Na}^{\cdot}$ as well as of $\mathrm{Cl}^{\prime}$, which we have shown, would apparently completely explain the unique action of $\mathrm{NaCl}$ as consisting simply in the fact that it is the only one of this long list of salts containing both of the ions specifically required for plasma repair. A much more elaborate explanation has been put forward by these authors. In interpreting the findings from their many experiments, they use the conception, derived from the work of Whipple, that the symptoms and death following obstruction are due to absorption of a toxic body. The accumulation of urea and of nonprotein nitrogen in the plasma is not referred to renal disability following dehydration, but to rapid destruction of protoplasm caused by the poisonous agent. The lowering of $\left(\mathrm{Cl}^{\prime}\right)$ in the plasma they state can only in part be explained by loss in vomited secretions since it is found when vomiting is slight and also in rabbits, an animal which cannot vomit. They infer that $\mathrm{Cl}^{\prime}$ leaves the plasma in quest of the toxic body. The benefit of the administered $\mathrm{NaCl}$ is therefore described as protective rather than reparative (13).

Obviously the few data given in this paper do not justify our contesting the views which Haden and Orr have developed from their extensive studies. However, they at least indicate, we believe, that the physical explanation (dehydration) of the events following pyloric or upper intestinal obstruction and of the beneficial effect of $\mathrm{NaCl}$ solution should be thoroughly tested as regards its sufficiency before accepting the additional and not easily credible hypothesis which these authors have devised.

\section{SUMMARY}

Following obstruction of the pylorus, there occurs in the vomited stomach secretions a loss of $\mathrm{Na}^{\cdot}$ as well as of $\mathrm{Cl}^{\prime}$ from the body. The sum of the concentrations of the acid radicals in the body fluids being determined, owing to adjustability of $\left(\mathrm{HCO}_{3}{ }^{\prime}\right)$, by the fixed base concentration, a loss of $\mathrm{Cl}^{\prime}$ does not deplete the total ionic concentration whereas loss of $\mathrm{Na}$ does and also removes an equivalence of $\mathrm{HCO}_{3}{ }^{\prime}$. Reduction of the ionic content of the body fluids by withdrawal of $\mathrm{Na}$ is the significant factor in the rapid dehydration following pyloric obstruction. Dehydration cannot be repaired by the introduction 
of water alone (glucose solution) or of water and the chloride ion $\left(\mathrm{NH}_{4} \mathrm{Cl}\right.$ solution). The efficacy of $\mathrm{NaCl}$ solution in sustaining the usual volume of body fluids is due to replacement of the loss of $\mathrm{Na}^{\circ} \cdot$

The increase of $\left(\mathrm{HCO}_{3}{ }^{\prime}\right)$ in the plasma, which tends to occur following pyloric obstruction, is an automatic consequence of the depletion of $\left(\mathrm{Cl}^{\prime}\right)$. The degree of alkalosis is, however, usually greatly lessened by reduction of plasma base due to loss of $\mathrm{Na}^{\circ}$; by extension of the base equivalence of plasma protein caused both by an increase in concentration of protein and of plasma alkalinity; and, possibly, by an increase in the concentration of organic acids.

Following administration of $\mathrm{NaCl}$ solution, the surplus of $\mathrm{Na}$. over $\mathrm{Cl}^{\prime}$ presenting for excretion, owing to the greater depletion of the latter, is conveyed into the urine as bicarbonate.

\section{CHEMICAL METHODS}

Blood serum: Using a Luer syringe, samples were taken from the jugular vein and then delivered through small bore glass tubing under oil into a centrifuge tube. Chlorides were determined by a modification of the Van Slyke procedure essentially as described by Myers and Short (14). Bicarbonate was measured by the method of Van Slyke (15) and ketone acids by the method of Van Slyke and Fitz (16). The methods of Kramer and Tisdall were used in determining sodium and calcicom $(17,18)$. Phosphate was measured by the method of Howland, Haessler, and Marriott (19), and urea by a micro modification of the urease method. Protein was calculated from a determination of plasma refractivity according to Robertson (20).

Vomitus: Sodium and potassium were determined in ashed samples by the methods of Tisdall and Kramer (21) and chloride as in blood serum. Protein was calculated from a Kjeldahl measurement of nitrogen and $p H$ was determined colorimetrically.

Urine: The specimens were obtained by catheter and were collected under oil. Bicarbonate was calculated from measurements of total $\mathrm{CO}_{2}$ and of $\mathrm{pH}$ according to Gamble (8). Phosphates (inorganic) were determined by the uranium acetate method. Sulphates (inorganic) were weighed as barium sulphate according to the method of Folin (22). Chlorides were determined as in blood serum. The organic acid excretion was measured by the method of Van Slyke and Palmer (23). $p H$ was determined colorimetrically under oil, using the comparator method of compensating for the color of the specimen. The measurements were made at room temperature.

${ }^{6}$ Although it is here argued that loss of $\mathrm{Cl}^{\prime}$ is not significant as regards the causation of dehydration, its replacement along with $\mathrm{Na}{ }^{\circ}$ is obviously necessary in order to prevent alkalosis. 


\section{BIBLIOGRAPHY}

1. Gamble, J. L., Ross, S. G., and Tisdall, F. F. Jour. Biol. Chem., 1923, lvii, 633.

2. Gamble, J. L., Blackfan, K. D., and Hamilton, B. Jour. Clin. Invest., 1925, i, 359 .

3. MacCallum, W. G., Lintz, J., Vermilye, H. N., Leggett, T. H., and Bras, E. Bull. Johns Hopkins Hosp., 1920, xxxi, 1.

4. McCann, W. S. Jour. Biol. Chem., 1918, xxxv, 553.

5. Haden, R. L., and Orr, T. G. Jour. Exper. Med., 1923, xxxvii, 377.

6. Hastings, A. B., Murray, C. D., and Murray, H. A., Jr. Jour. Biol. Chem., 1921, xlvi, 223.

7. Haden, R. L., and Orr, T. G. Jour. Exper. Med., 1923, xxviii, 55.

8. Ross, S. G. Canadian Med. Assoc. Jour., 1923, 1.

9. Gamble, J. L. Jour. Biol. Chem., 1922, li, 295.

10. Hartwell, J. A., and Hoguet, J. P. Jour. Amer. Med. Assoc., 1912, lix, 82.

11. Haden, R. L., and Orr, T. G. Jour. Exper. Med., 1923, xxvii, 365.

12. Haden, R. L., and Orr, T. G. Jour. Exper. Med., 1924, xxxix, 321.

13. Haden, R. L., and Orr, T. G. Jour. Amer. Med. Assoc., 1924, lxxxii, 1515.

14. Myers, V. C., and Short, J. J. Jour. Biol. Chem., 1920, xliv, 47.

15. Van Slyke, D. D. Jour. Biol. Chem., 1917, xxx, 347.

16. Van Slyke, D. D., and Fitz, R. Jour. Biol. Chem., 1917, xxxii, 495.

17. Kramer, B., and Tisdall, F. F. Jour. Biol. Chem., 1921, xlvi, 467.

18. Kramer, B., and Tisdall, F. F. Jour. Biol. Chem., 1921, xlvii, 475.

19. Howland, J., Haessler, F. H., and Marriott, W. McK. Jour. Biol. Chem., 1916, xxiv, xviii.

20. Robertson, T. B. Jour. Biol. Chem., 1912, xi, 179.

21. Tisdall, F. F., and Kramer, B. Jour. Biol. Chem., 1921, xlviii, 1.

22. Folin, O. Jour. Biol. Chem., 1905-06, i, 131.

23. Van Slyke, D. D., and Palmer, W. W. Jour. Biol. Chem., 1920, xli. 567. 